\title{
Preparation of Sensitivity Test Antibiotic Discs Using Some Nanomaterials to Detect Resistance of Pseudomonas Aergenosa to Some Antibiotics
}

\author{
Zainab J. Ghaneim, May M. Ismzil, Ilham A. Khalaf*, Juan F. Mustafa, Shatha A. Mahmood, Alya M.
} Abdulaa

Al-Razi Center for Research \& Medical Kits Production/ Corporation of Research and Industrial Development Iraq

Article information

\section{Article history:}

Received: October, 06, 2021

Accepted: October, 10, 2021

Available online: October, 20, 2021

Keywords:

Bentonite nanoparticles,

Biofilm bacteria,

Bacteria resistance

*Corresponding Author:

Ilham A. Khalaf

elhamkalaf66@gmail.com

DOI:

https://doi.org/10.53523/ijoirVol8I2ID95

\begin{abstract}
This study was conducted to synthesize bentonite nanoparticles and load them on different antibiotics to increase the effectiveness of the antibiotics or treat the resistance of Pseudomonas aeruginosa to some types of antibiotics in the laboratory. The biosynthesized bentonite nanoparticles were characterized by spectrophotometry and scanning electron microscopy. Their antibacterial activity against Pseudomonas aeruginosa was determined by the (muller-hinton) method of diffusion in plates compared with antibiotics using different concentrations of each ranging from $12.5-200 \mu \mathrm{g} / \mathrm{ml}$. The results of this study showed that it is possible to synthesize bentonite nanoparticles in an easy and environmentally friendly manner, and the maximum absorption spectra of these nanoparticles were at 420 and $430 \mathrm{~nm}$ using a spectrophotometer. The scanning electron microscope analysis also showed that the average diameter of these particles was 26 nanometers, in addition to their high activity against bacteria.
\end{abstract}

\section{Introduction}

The word nano derives from the Greek word "nanos" which means dwarf, which refers to things with a size of one billion (9-10) nanometers. These characteristics have led to the provision of simple techniques for the production and synthesis of metallic nano-sized particles. Nanoparticles provide solutions to environmental and technological challenges in many fields, and these advantages depend largely on the shape and total size of the particles and their distribution [1]. Pseudomonas aeruginosa is a widely distributed Gram-negative bacterium that can cause disease in animals and humans. These bacteria are found in soil, water, plants, skin, and most environments, both natural and man-made, and are found all over the world [2]. These bacteria thrive in natural environments, but also in lowoxygen atmospheres, and then expanded to include many natural and artificial environments. In the animal environment, it feeds on a wide range of organic materials, and also has multiple possibilities. When infecting the organism, it destroys its tissues and infects organisms that suffer from immunodeficiency. Symptoms of its diseases are sepsis. If its spread occurs in vital body systems, such as the lungs, urinary tract or kidneys, it can be fatal [3]. 
Because they feed on wet surfaces, these bacteria can be found in medical equipment, such as catheters, and so are also among the infections that hospitals can cause. It is also one of the causes of hot bath rash. It is also able to break down hydrocarbons and has been used to crack tar and oil when an oil spill occurs [4].

Pseudomonas aeruginosa has enormous potential to develop resistance against antibiotics as is evident from the fact that the human genome contains the largest resistance ground with more than 50 resistance genes [5]. Mechanisms of latent antibiotic resistance have been found to include production of degrading or enzymeinactivating antibiotics, outer membrane proteins to flush out antibiotics and mutations to change the antibiotic target. The presence of antibiotic degrading enzymes such as extended-spectrum PER-1, PER-2, VEB-1, AmpC, cephalosporinases, carbapenemases like serine oxacillinases, metallo-b-lactamases, OXA-type carbapenemases, aminoglycoside-modifying enzymes, among others has been reported. Pseudomonas aeruginosa can disrupt the mechanism of action of antibiotics such as methylation of $16 \mathrm{~s}$ rRNA to prevent aminoglycosides from binding and modifying topoisomerase DNA and protect it from the effect of quinolones [6].

Pseudomonas aeruginosa has a multidrug pump such as AdeABC and the AdeDE escape system that confer resistance against a number of classes of antibiotics [7]. An important factor was found to be associated with antibiotic resistance, which is the reduced capabilities of the resistance strain as in rifampicin resistance and colistin resistance, which witness a decrease in infectious capacity, and quorum sensing and movement have been documented in them [8]. This seems to indicate that due to the lack of competition after antibiotic therapy, for these strains of Pseudomonas aeruginosa, we have had a limited number of treatment options. Polymyxine, Carbapenems and Tigecyeline have recently been considered a drug option [9]. The mechanisms of Action by which Nano-Antibiotics Kill the Bacteria in Question:

1. Production of reactive oxygen species such as hydrogen peroxide $\mathrm{H}_{2} \mathrm{O}_{2}, \mathrm{OH}$ and oxygen $\mathrm{O}_{2}$.

2. Disruption of the will cell wall.

3. Inhibition of DNA synthesis and intracellular enzyme activity.

4. Cut off energy access to bacteria [10].

The main focus of this research conducted on the production of nano bentonite which can used in pharmaceutical formula aspect, by using co-precipitation modified method. Bentonite nanoparticles have traditionally been used in many applications such as treatment skin cancer and other organs, skin chemotherapy, and medicine to improve the human health and life. In addition, they have recently been developed as additives, lubricants, and active materials in pharmaceutical formulation and other applications.

Nanomaterials can preferentially deliver antibiotics to the bacteria, a mechanism that enhances drug potency by reducing overall drug exposure. These nanomaterials - based drug carriers can over com cellular barriers and deliver antibiotics to the cytoplasm to kill intracellular bacteria.

Pseudomonas aeruginosa is an ideal model for opportunistic pathogens. One of the disturbing characteristics of Pseudomonas aeruginosa is its lack of sensitivity and its susceptibility to antibiotics. This characteristic is due to the pumps located at the level of the biofilm, which has the ability to withstand external factors and external stress, as it protects bacteria from antibiotics and works to pump several drugs, including antibiotics, out of the cell [11].

\section{Experimental Procedure \\ Materials Used to Grow Bacteria}

1. Molar Hinton agar / NEOGEN Corporation

2. Nutrient agar / BIOLIFE Company

3. Nutrient broth / BIOLIFE Company

4. Gram stain / HIMEDIA

\section{Devices Used}

$>$ Incubator / Binder company of German origin.

$>$ Centrifuge Centrifuge / HETTICH company of German origin.

$>$ Oven oven / Binder company of German origin. 
$>$ Hood class II sterilization booth / TELSTAR company of Spanish origin.

$>$ Autoclave sterilizer / HIRAYAMA company of German origin.

$>$ Optical Microscope / OPTICA company of Italian origin.

$>$ Cleaver Balance

$>$ microwave

$>\mathrm{Ph}$ meter (Hanna)

\section{Working Methods}

Bacteria isolated from burns and wounds were grown in enriched media for 24 hours, prepared by higher education and registered in the gene bank for the purpose of stimulating bacterial growth. Or bacterial appears to us clearly in the slide requires the destruction of isolation.

\section{Preparation of Liquid Culture Medium}

1. prepare brain heart infusion broth, according to the working method of the company.

2. Distribute the medium in sterile tubes with a capacity of $5 \mathrm{ml}$.

3. The tubes containing the media were sterilized by autoclaving at $121^{\circ} \mathrm{C}$ at atmospheric pressure of 1 at (bar).

1. Culture of bacteria in liquid medium

1. culture bacterial growth in the liquid medium.

2. The tubes were incubated in the incubator at $37^{\circ} \mathrm{C}$ for 24 hours.

3. Then it was implanted on solid nutrient media to perform the MIC. examination

\section{Microscopy}

The bacterial growth was examined after incubation by making slides and dyed with a cream dye according to the producing company and examined with a light microscope at a power of 100X)).

\section{Nanomaterials}

convert natural bentonite to nanoparticle:

Materials used:

Natural bentonite from the soil of western Iraq.

$\mathrm{HCl}$ acid.

Deionized water.

\section{Used Equipments}

$>$ Mortar Muller

$>$ Magnetic stir

\section{Method of Work}

The bentonite was obtained from the Iraqi Geological Survey from the soil of western Iraq, then the natural bentonite was crushed and ground by a regular mill, and then the powder was sieved by a size 45 sieve into a powder with an average particle size of less than 100 micrometers. After that, the stage of converting natural bentonite into nanoparticles by the co-precipitation and purification method development method begins

The first step is to dry the natural bentonite powder using an oven at a temperature of 80 degrees Celsius for 5 hours until it dries completely. Then the process of chemical activation of the bentonite powder is carried out by a chemical reaction, where $250 \mathrm{gm}$ of bentonite is dissolved in $500 \mathrm{ml}$ of hydrochloric acid at a conc entration of 0.1 molarity and by using a magnetic stirrer to mix the solution at 300 doses per minute at a temperature of $70{ }^{\circ} \mathrm{C}$ for 5 hours, then the process of washing the solution using water Deionized with filtration and this process was repeated 15 times with mixing at $300 \mathrm{rpm}$ at room temperature to obtain a $\mathrm{pH}$-neutral bentonite solution and this process continued for 72 days. Then the solution is dried at room temperature. After the drying process, the powder is burned using an oven at $600^{\circ} \mathrm{C}$ for 5 hours.

Finally, the powder was ground with a mill (HEM) for $6 \mathrm{~h}$ to obtain a particle size of about (1-100 nm), and atomic force microscopy (AFM) and scanning electron microscopy (SEM) were used for characterization. From the characterization results it was reported that the average size of bentonite nanoparticles is $0-99.08 \mathrm{~nm}$. The special 
properties of bentonite (hydration, swelling, water absorption, viscosity, thixotropy) make it a valuable material for a wide range of uses and applications.

\section{Results and Discussion}

The morphology of bentonite was studied using Atomic Force Microscopy at 444.45-pixel density. The two- and three dimensional surface profiles of nanoparticle bentonites are shown in Figs. 1 and 2. The results of particle size distribution showed that the average particle diameter is $0-99.08 \mathrm{~nm}$.

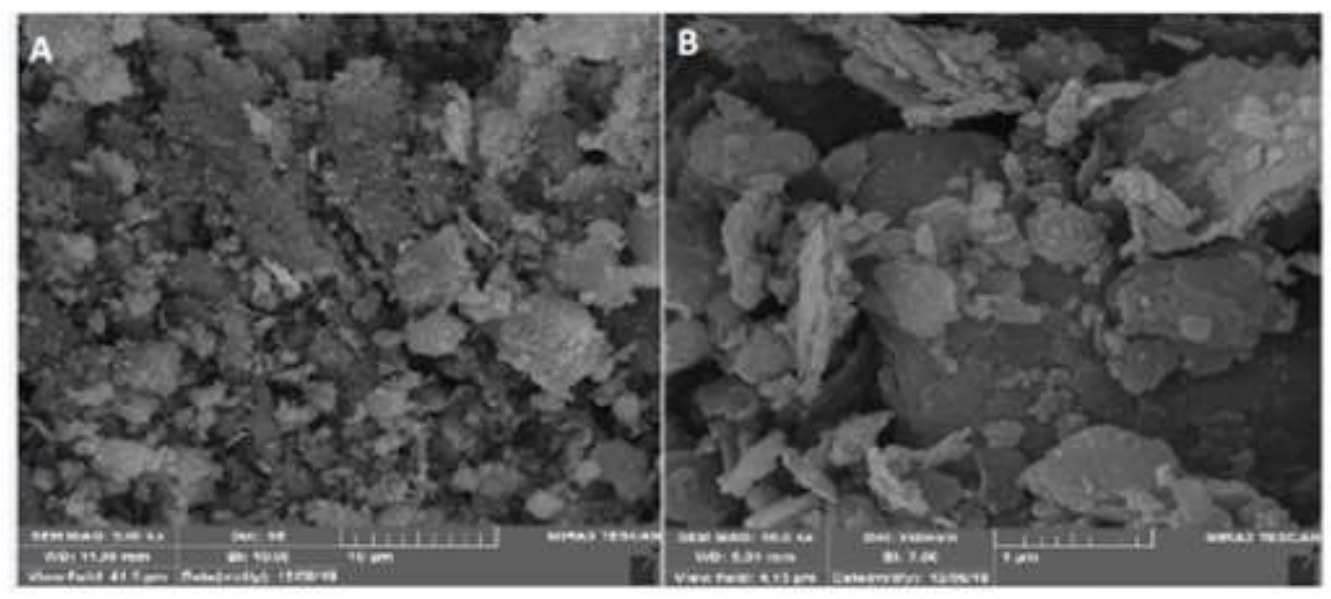

Figure (1). Microstructure Nano Particle Bentonite.
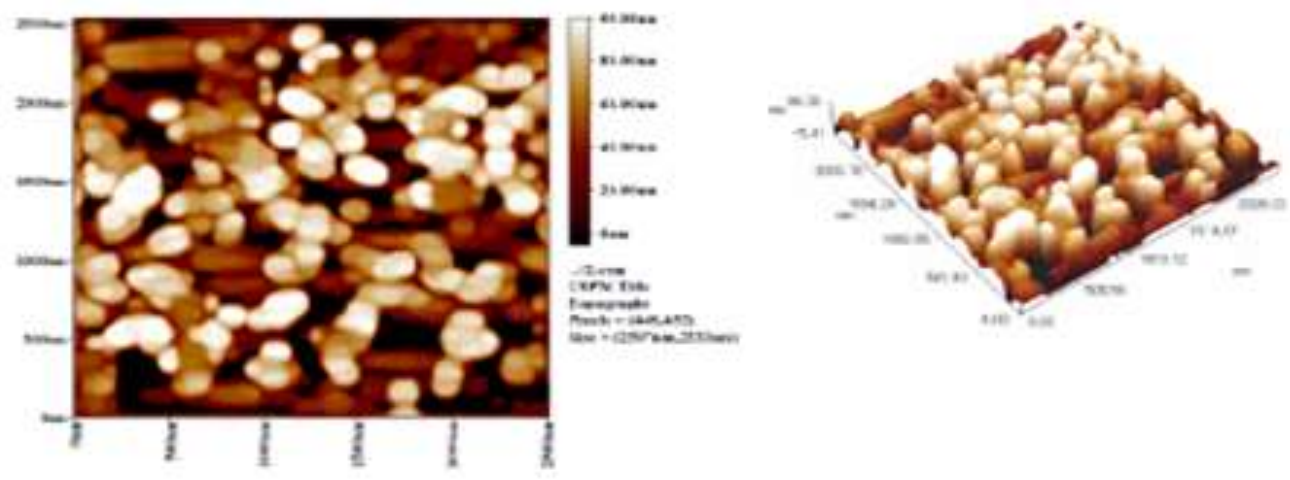

Figure (2). AFM analysis of nanopartical Iraqi bentonite

Molecular diagnosis of pseudomonas aeruginosa by detection of housekeeping gene (16srRNA, pelA) using uniplex-PCR are shown in Figs. 3. 

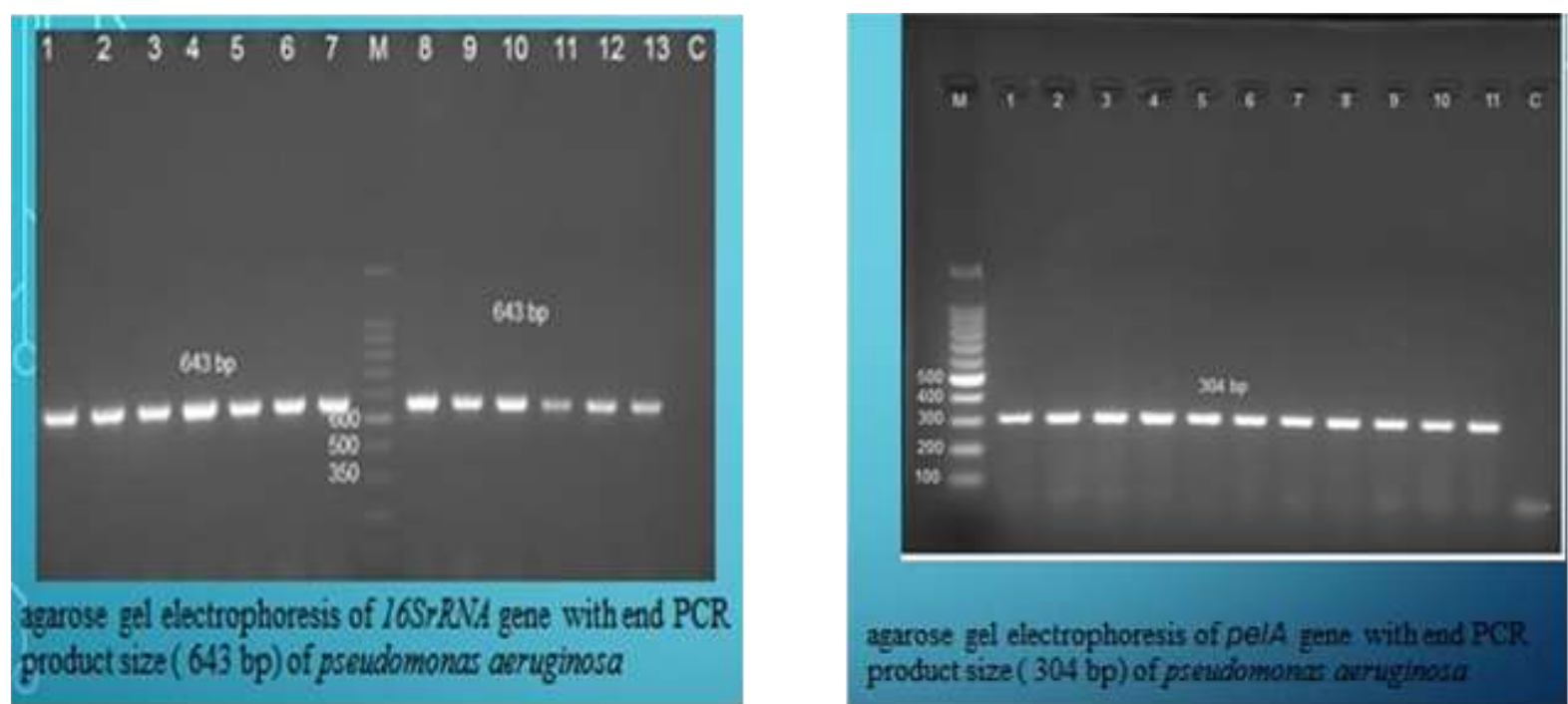

Figure (3).Molecular identification of bacteria.

Table (1). The Composition of Bentonite

\begin{tabular}{|l|l|}
\hline Element & Composition \% wt \\
\hline C & 2.44 \\
\hline O & 42.55 \\
\hline Mg & 4.09 \\
\hline Al & 13.39 \\
\hline Si & 33.05 \\
\hline K & 1.10 \\
\hline Ca & 1.35 \\
\hline Ti & 0.79 \\
\hline Fe & 1.29 \\
\hline Total & 100 \\
\hline
\end{tabular}

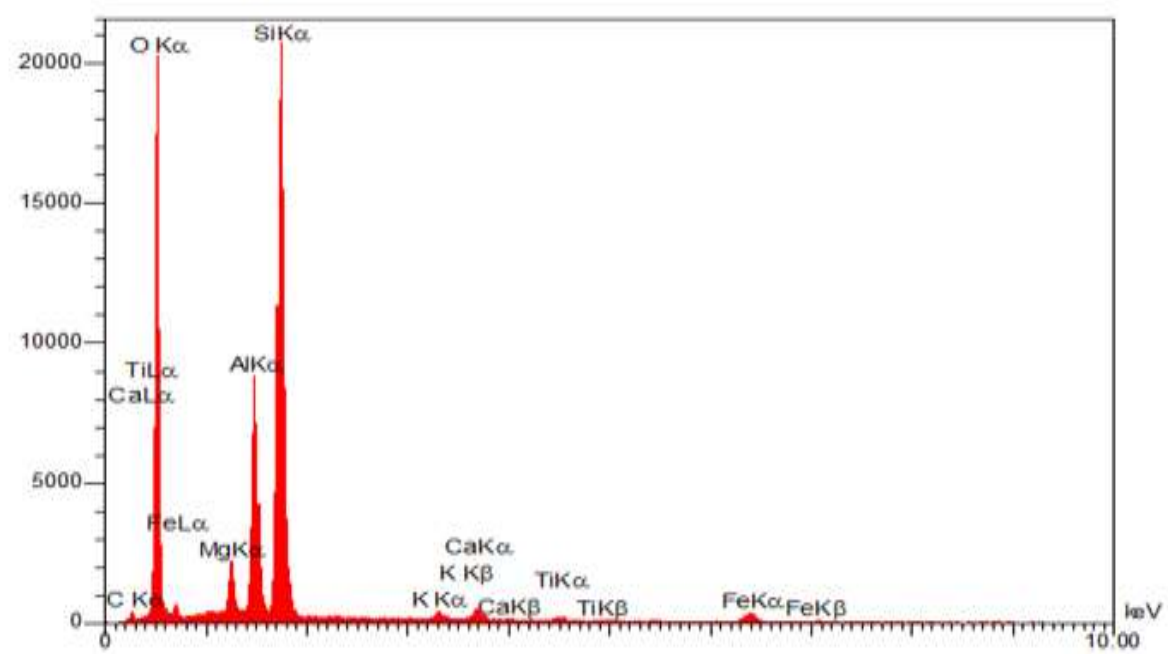

Figure (4). Analysis Elements with Scanning Electron Microscopy (SEM) 


\section{Biological Examination}

The Kirby and Bauer bioassay technique was carried out using Pseudomonas aergenosa.

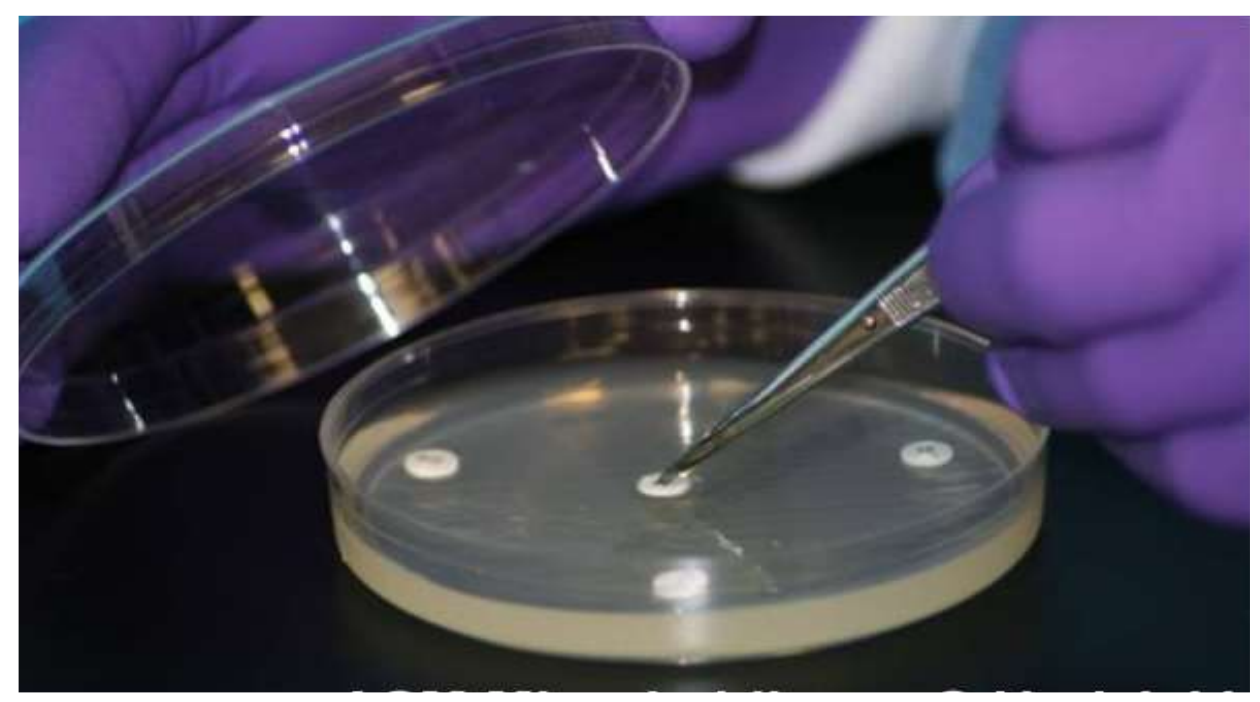

Figure (5). The Kirby and Bauer bioassay technique.

The efficacy of synthetic nanoparticles (bentonite) was tested, as it was based on four different concentrations $(0.2 \mathrm{mg}, 0.15 \mathrm{mg}, 0.1 \mathrm{mg}$ and $0.5 \mathrm{mg}) / 1 \mathrm{ml}$ of distilled water against Pseudomonas aeruginosa bacteria at a concentration of $0.5 \mathrm{MacFarl}$ and.

\section{Susceptibility Analysis}

Antibiotic susceptibility examination of the isolated bacteria was done via disc diffusion method using the modified Kirby-Bauer method and Vitik2 [11].

\section{Molecular Identification of Bacteria}

Molecular diagnosis of pseudomonas aeruginosa by detection of housekeeping gene (16srRNA, pelA) using uniplex-PCR.

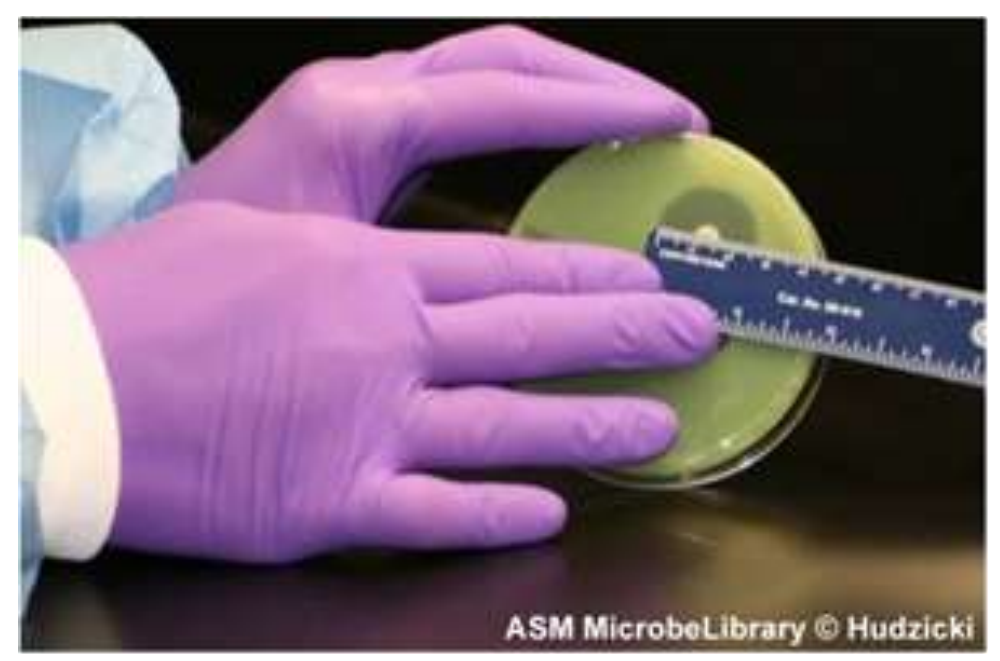

Figure (6). The Kirby and Bauer bioassay technique calculation method. 
Table 2:

Pseudomonas aeruginosa and other non-fermenting Gram Negative Rods (Zone Diameter, nearest whole $\mathrm{mm}$ )

\begin{tabular}{|l|c|c|c|}
\hline & Resistant & Intermediate & Susceptible \\
\hline Amikacin $(30 \mu \mathrm{g})$ & $\leq 14$ & $15-16$ & $\geq 17$ \\
\hline Cefoperazone $(75 \mu \mathrm{g})$ & $\leq 15$ & $16-20$ & $\geq 21$ \\
\hline Cefotaxime $(30 \mu \mathrm{g})$ & $\leq 14$ & $15-22$ & $\geq 23$ \\
\hline Gentamicin $(10 \mu \mathrm{g})$ & $\leq 12$ & $13-14$ & $\geq 15$ \\
\hline Piperacillin $(100 \mu \mathrm{g})$ & $\leq 17$ & -- & $\geq 19$ \\
\hline Tetracycline $(30 \mu \mathrm{g})$ & $\leq 14$ & $15-18$ & $\geq 15$ \\
\hline Ticarcillin $(75 \mu \mathrm{g})$ & $\leq 14$ & -- & $\geq 15$ \\
\hline Tobramycin $(10 \mu \mathrm{g})$ & $\leq 12$ & $13-14$ & \\
\hline
\end{tabular}

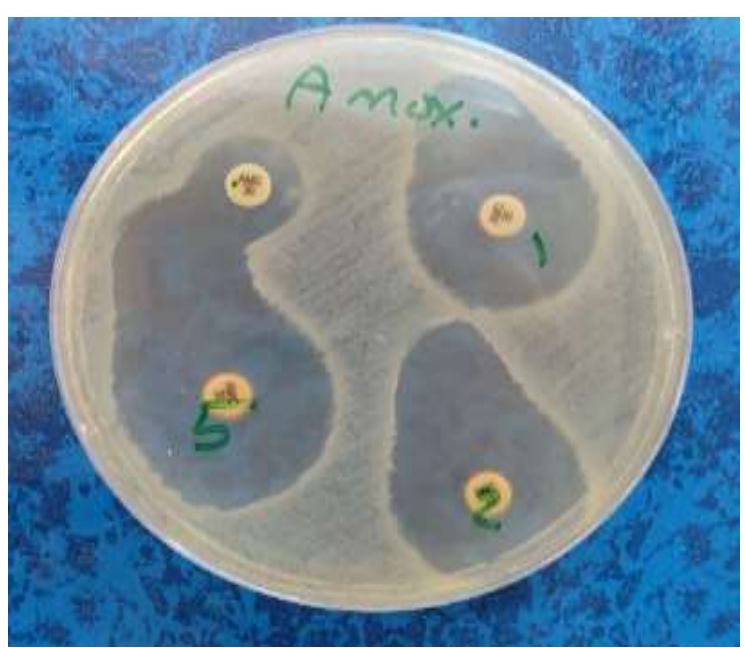

Amoxycilline: $0.05,0.025,0.01 \mathrm{mg}$ pentonate per $2 \mathrm{ml}$ DW

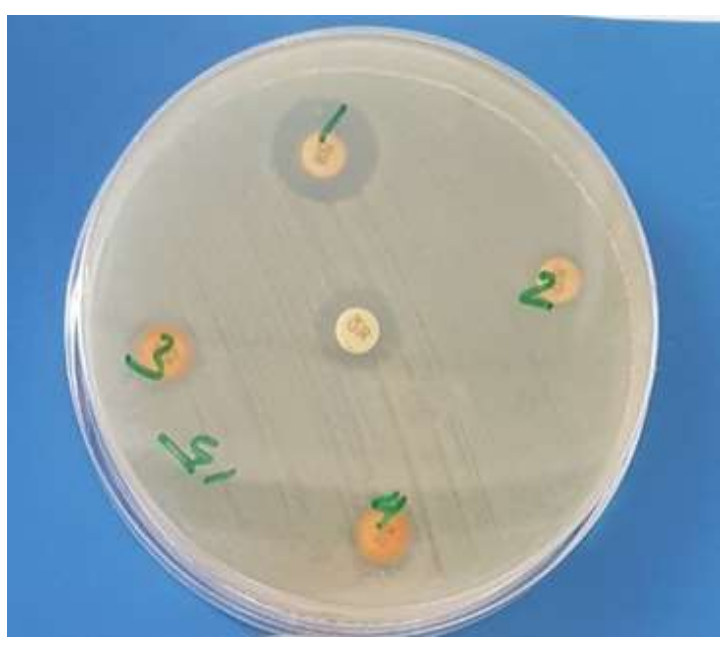

Cefixtin:0.05,0.10,0.15,0.20mg pentonate per $2 \mathrm{ml}$ DW

Figure (7). Inhibition zone diameter of antibiotic and combination of antibiotic and Bentonate. 


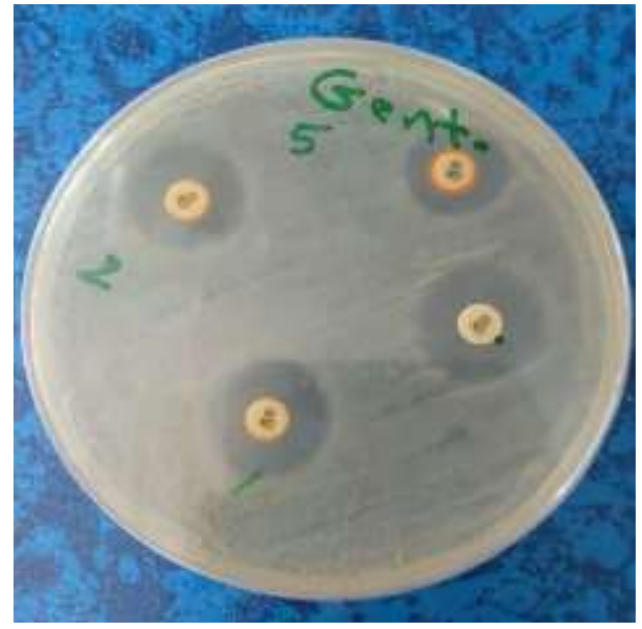

Gentamycin:0.05,0.03,0.01mg Bentonate per $2 \mathrm{ml}$ DW

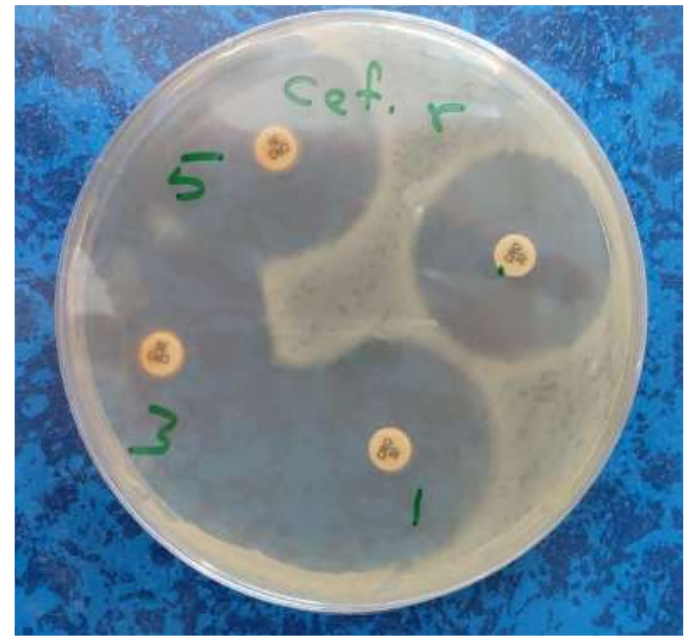

Cefitrixone :0.05,0.03,0.01mg Bentonate per $2 \mathrm{ml} \mathrm{DW}$

Figure (8). Inhibition zone diameter of antibiotic and combination of antibiotic and Bentonate
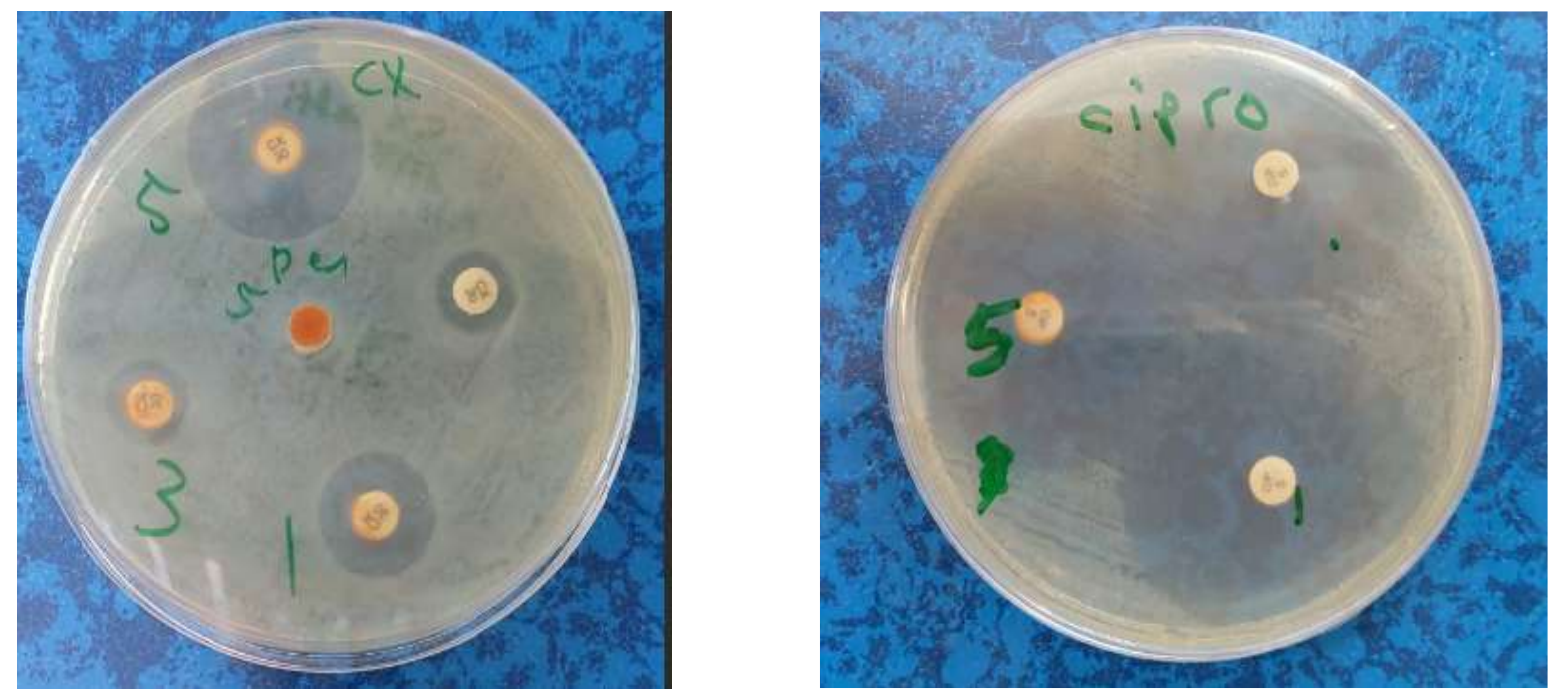

Cefixtine 0.05,0.03,0.01 mg pentonate per $2 \mathrm{ml} \mathrm{DW}$ Ciprofloxacin: $0.05,0.01 \mathrm{mg}$ pentonate per $2 \mathrm{ml} \mathrm{DW}$

Figure (9). Inhibition zone diameter of antibiotic and combination of antibiotic and Bentonate. 

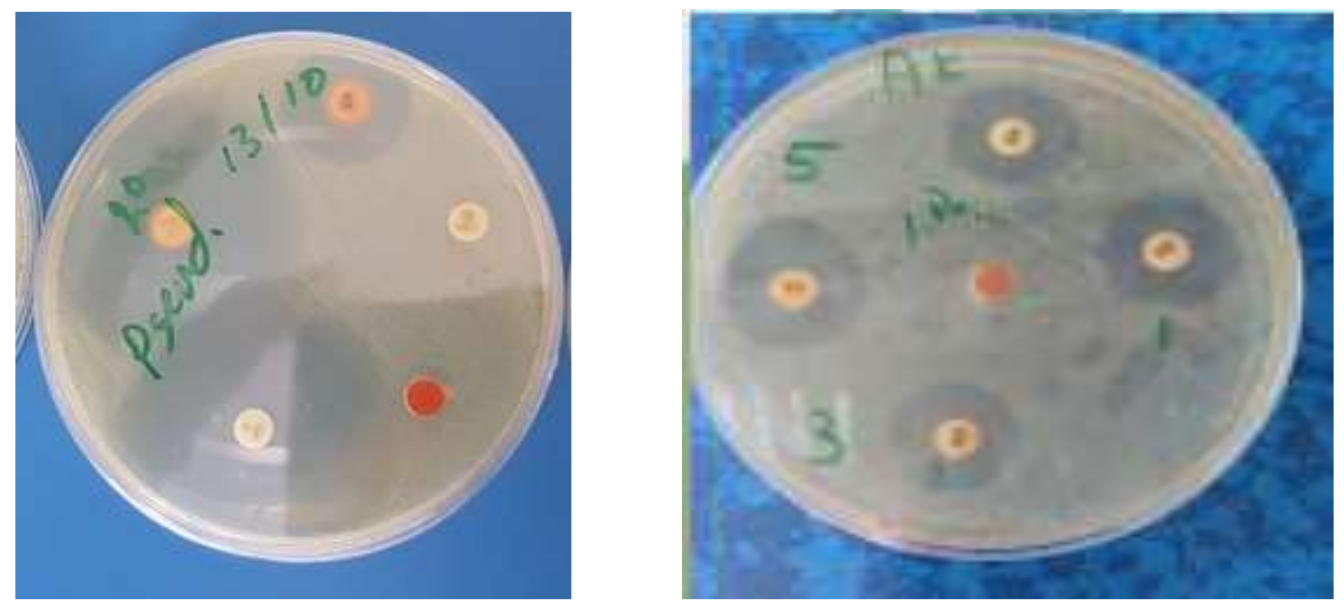

Figure (10). Cephalothin, Amikacin inhibition zone :0.20,0.15,0.01,0.05mg bentonate in $2 \mathrm{ml}$ DW.

Table (3). Inhibition zone (mm) for just antibiotic (Ab), antibiotic and bentonate $0.5,0.050 .025 \mathrm{mg} / 2 \mathrm{ml}$ Distilled water (DW).

\begin{tabular}{|c|c|c|c|c|c|}
\hline \multirow{2}{*}{ No. } & \multirow{2}{*}{ Antibiotic disc(Ab) } & Just Ab & $\begin{array}{c}\text { Ab+bentonite } \\
\mathbf{0 . 5}\end{array}$ & $\begin{array}{c}\text { Ab+bentonite } \\
\mathbf{0 . 0 5}\end{array}$ & $\begin{array}{c}\text { Ab+bentonite } \\
\mathbf{0 . 0 2 5}\end{array}$ \\
\cline { 3 - 6 } & & \multicolumn{4}{|c|}{ Inhibition zone } \\
\hline 1 & Cephalothin & --- & $25 \mathrm{mml}$ & $5 \mathrm{mml}$ & \\
\hline 2 & Cefotoxin & $10 \mathrm{mml}$ & $16 \mathrm{mml}$ & $27 \mathrm{mml}$ & $17 \mathrm{mml}$ \\
\hline 3 & Amikacin & $25 \mathrm{mml}$ & $34 \mathrm{mml}$ & $20 \mathrm{mml}$ & \\
\hline 4 & Ciprofloxacin & $42 \mathrm{mml}$ & $50 \mathrm{mml}$ & $50 \mathrm{mml}$ & $45 \mathrm{mml}$ \\
\hline 5 & Gentamcin 10 mcg & $20 \mathrm{mml}$ & & $15 \mathrm{mml}$ & $20 \mathrm{mml}$ \\
\hline 6 & Amoxicillin +calvunic acid & $15 \mathrm{ml}$ & & $38 \mathrm{mml}$ & $28 \mathrm{mml}$ \\
\hline 7 & Ceftriaxone & $32 \mathrm{mml}$ & & $32 \mathrm{mml}$ & $32 \mathrm{mml}$ \\
\hline 8 & Tetracycline & $10 \mathrm{mml}$ & & $25 \mathrm{mml}$ & $22 \mathrm{mml}$ \\
\hline 9 & Imipenim & $30 \mathrm{mml}$ & & $25 \mathrm{mml}$ & $22 \mathrm{mml}$ \\
\hline 10 & Bacitracin & $30 \mathrm{mml}$ & & $32 \mathrm{mml}$ & $32 \mathrm{mml}$ \\
\hline 11 & Optachin & $20 \mathrm{mml}$ & & $15 \mathrm{mml}$ & $20 \mathrm{mml}$ \\
\hline 12 & Pipracillin & $30 \mathrm{mml}$ & & $32 \mathrm{mml}$ & $34 \mathrm{mml}$ \\
\hline 13 & Vancomycin & $10 \mathrm{mml}$ & & $10 \mathrm{mml}$ & $10 \mathrm{mml}$ \\
\hline 14 & Nitrofurantin & $12 \mathrm{mml}$ & & $32 \mathrm{mml}$ & $32 \mathrm{mml}$ \\
\hline 15 & Azetronam & $30 \mathrm{mml}$ & & & \\
\hline
\end{tabular}

\section{Conclusions}

Nanomaterials can preferentially deliver antibiotics to the bacteria, a mechanism, that enhances drug potency by reducing overall drug exposure. These nanomaterials - based drug carriers can break down cellular barriers and deliver antibiotics to the cytoplasm to kill intracellular bacteria.

Two-dimensional bentonite clay nanoparticles are used in the drug delivery system. The increasing of spacing of the bentonite nanoparticles from $0-99.08 \mathrm{~nm}$ is due to the interference of guest species with different chain lengths of organic materials that can increase the drug delivery efficiency and reduce the toxicity of cancer drug.

Bentonite clay nanoparticles are used in the drug delivery system. The increasing of spacing of the bentonite nanoparticles from 0- $99.08 \mathrm{~nm}$ is due to the penetration the particles through papilloma result infected from vires. Bentonite combined with antibiotics have a highly inhibitory effect on the pseudomonas aeruginosa (MDR) which increased the antibiotic effect and reduced the resistance of the bacterial antibiotics.

Bentonate alone have not any antibiotic effect (inert). 


\section{References}

[1] G. A. Plaza, J. Chojniak, and I.M. Banat, "Biosurfactant Mediated Biosynthesis of selected Metallic Nanoparticles". International Journal of Molecular Sciences, vol. 15, p. 13720-13737, 2014.

[2] C. R. Raymond, F. R. Pharm, and P. J. Sheskey, "Handbook of Pharmaceutical Excipients," $6^{\text {th }}$ ed., Pharmaceutical Press, 2009.

[3] H. N. Hassan, and K. H. I. Ghassan, "Detection of some aminoglycoside resis-tance gene in Pseudomonas aeruginosa cultured from mastitic milk cows". Kufa Journal for Veterinary Medical Sciences, vol.7, p. 26 30, 2019.

[4] B. Shrivastava, "Medical Bacteriology", 9 $9^{\text {th }}$ ed., Lambart Academic publishing, 2011.

[5] J.Y. Choi, C.D. Sifiri, B.C. Goumnerow, L.G. Rahme, , et al., "Identification of virulence genes in a pathogenic strain of Pseudomonas aeruginosa representational difference analysis" . Journal of Microbiology, vol.184, p. 925-961, 2002.

[6] L. Hall-Stoodly, and P. Stoodley, "Evolovingcocepts in biofilm infection". Cellular Microbiology, vol.11, p.1034-1043, 2009.

[7] S. Manoharadas, M. Altaf, A. Alrefaei, R. Devasia, et al., "Concerted dispersion of Staphylococcus aureus biofilm by bacteriophage and 'green synthesized' silver nanoparticles". RSC Advances., vol.11, p. 1420$1429,2021$.

[8] A. Wright, C. H. Hawkin, E. E. Anggard et al., "A controlled clinical trial of a therapeutic bacteriophage preparation in chronic otitis due to antibiotic-resistant Pseudomonas aeruginosa; a preliminary report of efficacy". Clinical Otolaryngology, vol.34, p. 349-357. 2009.

[9] Y. Xie, Y. He, P.L. Irwin, et al., "Antibacterial activity and mechanism of action of zinc oxide nanoparticle against Campylobacter jejuni". Applied and Environmental Microbiology Journal, vol. 77, p. 2325$2331,2011$.

[10] W. Kim, Z. Tengra, J. Shong, Marchand et al., "Spaceflight promotes biofilm formation by Pseudomonus auregenosa". PLoS ONE, vol.8 p. e62437, 2013.

[11] P.A. Wayne, "Clinical Laboratory Standards Institute. Performance standards for antimicrobial disk susceptibility tests; Approved standard" $9^{\text {th }}$ ed., CLSI document M2-A9. 26:1. Clinical Laboratory Standards Institute, 2006. 